\title{
Power to the People?
}

\author{
Michael A. Ashby • Bronwen Morrell
}

Received: 3 October 2017 / Accepted: 10 October 2017 /Published online: 15 November 2017

(C) Journal of Bioethical Inquiry Pty Ltd. 2017

Keywords Populism · Psychic development P Public engagement $\cdot$ Big data

So-called populism in the global political sphere is evident everywhere. Mistrust abounds in most countries: of political institutions, politicians, science, and business. People who see themselves as ordinary and mainstream express alienation from the locus of power and decision-making and are hostile to what are perceived to be intellectual or corporate elites and their policies and big ideas (globalism, multiculturalism, immigration, etc). The elites in turn provide plenty of hostages to fortune and thereby are susceptible to trenchant criticism. Democracy speaks in elections all over the world by electing people who play to the fears of their citizens. Political electioneering always plays fast and loose with the facts, but now successful leaders

M. A. Ashby $(\bowtie)$

Palliative Care Service, Royal Hobart Hospital, Tasmanian Health Service, and School of Medicine, Faculty of Health Sciences, University of Tasmania, 1st Floor, Peacock Building, Repatriation Centre, 90 Davey Street, Hobart, TAS 7000, Australia

e-mail: michael.ashby@ths.tas.gov.au

B. Morrell

Sydney Health Ethics, The University of Sydney, Level 1, Medical Foundation Building, K25, Camperdown, NSW 2006, Australia brazenly mirror and echo prejudice and fear with little regard to objectivity. So what happens when many feel that democracy in action increasingly throws up people or policies that we do not like?

Melanie Klein described two phases of human development (Melanie Klein Trust 2017). The first is the paranoid-schizoid state, that is, in this conceptualization, the normal psychic stage in childhood development as the child grows away from the mother and experiences the world in polarities: needs met and shunned, therefore as dichotomized into the good (that which meets the needs) and the bad (that which does not). This view of the world as composed of goodies and baddies is mirrored in the childhood games of cops and robbers, cowboys and indians. In this state, the psychic response to the outside world is one of splitting into those essentially who are for us and those who are against us. In healthy psychic development, the mature adult state is known as the depressive state, in which the world is understood as being more complex with people and situations being both good and bad and in which negotiation and consensus are required. The terminology, as with so many psychodynamic concepts, is technical and sounds odd to those outside the field. Fear tends to propel people into the first stage or keep them there. A politician who plays on the fears of the electorate therefore has a tendency to reinforce splitting in the community and a desire for primitive certainty and the identification of the other is bad. This is seen in political 
extremism and religious fundamentalism. In this state people are not curious and they are certainly not generous to those whom they oppose or perceive as enemies. It is also clear that when these fears are activated and the schizoid state is in play, deep analysis and understanding and any form of learning are suppressed. Ironically a journal like this one, no doubt written and read overwhelmingly by those who would see themselves as democrats, is not noticed by the masses, but if it were, it would be seen no doubt as the habitat of the philosopher kings (and queens) of the ancient Greek world. As such the sad reality is that it is hard to know how to communicate the sort of deep scholarship, justice, and curiosity that journals like the $J B I$ aspire to outside the academy. Hopefully, ripples come from these essays (meant in the literal derivation of the word from the French "essai," to try) that influence real events in the way the $J B I$ community and its contributors would wish.

It is also clear in for example, two of these contributions, that the schizoid position is dominant in the public arena, regardless of fact or reason. In Recent Developments, our regular legal column (Hammond-Browning 2017), we see the popular reaction to the plight of a dying boy in England with a rare genetic condition as his parents desperately try to access a new experimental treatment in the United States. The public campaign in the United Kingdom gained worldwide attention and the support of leading world figures including President Donald Trump. The fact that the U.K. courts understood well that he was beyond saving meant nothing in the court of public opinion.

The symposium "Ethics and Epistemology of Big Data" analyses some of the big evolving questions as the IT capacity to process vast amounts of data leads to suspicion that governments and corporations will use these data to the disadvantage of citizens (Lipworth, Mason, and Kerridge 2017). The fear of the other, or big brother type invasions of personal privacy, and the use of such data to the disadvantage of individual citizens is clearly a matter of concern. However in a climate of suspicion and profound lack of trust, important advantages of analysing large datasets may be lost. The complexities of obtaining consent for data analysis and tissue banks, especially when the data points may be numbered in the millions, are clearly challenging. The idea that an individual signs a consent form and is clear about what the data about them, or bits of them, will be used for, becomes much more complicated in such vast data networks. No matter how well de-identified, individuals still fear that they may be identified and the data used against their best interests. The fact that this is occurring at a time when mutual trust is so poor, means that progress is likely to be slow. The authors identify some of the new bioethical issues (for a list see Lipworth and colleague's [2017] introductory lead essay) that arise from big data analysis and, as ever, the authors are keen for bioethical scrutiny to be in step with technical progress, rather than chasing behind it.

The rest of the issue carries articles across a wide range of bioethics' "greatest hits" including conflict of interest (Grundy et al. 2017), consent of minors (Rost et al. 2017), withdrawal of treatment versus medical tourism/experimental treatment (Hammond-Browning 2017), assisted dying (Kirby 2017), and ethics in the context of war/tyranny (Mayaki 2017), as well as one of the latest, big hitters-moral bioenhancement (Rakić 2017). The methodologies are also diverse - two are empirical-one qualitative (Grundy 2017) and one quantitative (Rost 2017). One uses a comparative domains of ethics analysis (Kirby 2017), while another offers a critical response in the context of an ongoing debate with an academic interlocutor (Rakić 2017). The articles touch on a variety of ethical principles, concepts, and frameworks including autonomy, beneficence, nonmaleficence, best interests, freedom, power, professionalism, and utilitarianism, in a variety of settings including the clinic, the courts, and the national political arena.

So the answer to the question at the end of the first paragraph is hopefully encapsulated in this issue: keep on with deep, multi-faceted analysis via diverse methods from a broad range of disciplines. Be curious and open, uphold principles of fairness, justice, and human rights. Even if the crowd doesn't really notice, this all still needs to be said and hopefully it will percolate through and act as a counterbalance to harsher, less considered noise.

\section{References}

Grundy, Q., L. Tierney, C. Mayes, and W. Lipworth. 2017. Health professionals "make their choice": Pharmaceutical industry leaders' understandings of conflict of interest. Journal of Bioethical Inquiry 14(4). doi. 10.1007/s11673017-9804-y.

Hammond-Browning, N. 2017. When doctors and parents don't agree: The story of Charlie Gard. Journal of Bioethical Inquiry 14(4). doi. 10.1007/s11673-017-9814-9 
Kirby, J. 2017. Morally relevant similarities and differences between assisted dying practices in paradigm and nonparadigm circumstances: Could they inform regulatory decisions? Journal of Bioethical Inquiry 14(4). doi. 10.1007/s11673-017-9808-7.

Lipworth, W., P.H. Mason, and I. Kerridge. 2017. Ethics and epistemology of big data. Journal of Bioethical Inquiry 14(4). doi. 10.1007/s11673-017-9815-8

Mayaki, J.A. 2017. The president's physician: An African play. Journal of Bioethical Inquiry 14(4). doi. 10.1007 /s11673-017-9811-z.
Melanie Klein Trust. 2017. Theory. Melanie Klein Trust Website. http://www.melanie-klein-trust.org.uk/theory. Accessed October 23, 2017.

Rakić, V. 2017. The issues of freedom and happiness in moral bioenhancement: Continuing the debate with a reply to Harris Wiseman. Journal of Bioethical Inquiry 14(4). doi. 10.1007 /s11673-017-9805-x.

Rost, M., T. Wangmo, F. Niggli et al. 2017. Parents' and physicians' perceptions of children's participation in decision-making in paediatric oncology: A quantitative study. Journal of Bioethical Inquiry 14(4). doi. 10.1007 /s11673-017-9813-x. 